\title{
Combination of B-cryptoxanthin and zinc has potent effects on apoptotic cell death and suppression of bone resorption-related gene expression in osteoclastic cells
}

\author{
MASAYOSHI YAMAGUCHI ${ }^{1,2}$ and SATOSHI UCHIYAMA ${ }^{1}$ \\ ${ }^{1}$ Laboratory of Endocrinology and Molecular Metabolism, Graduate School of Nutritional Sciences, \\ University of Shizuoka, 52-1 Yada, Suruga-ku, Shizuoka 422-8526, Japan
}

Received December 24, 2007; Accepted March 11, 2008

DOI: 10.3892/ijmm_00000012

\begin{abstract}
We investigated whether the effect of $\beta$-cryptoxanthin (CRP) on osteoclastic cells formed in the mouse marrow culture system in vitro is enhanced by culture with zinc. Bone marrow cells were isolated from mice. The macrophage colony-stimulating factor (M-CSF)-dependent bone marrow macrophages were cultured in the presence of $\mathrm{M}-\mathrm{CSF}(10 \mathrm{ng} / \mathrm{ml})$ and receptor activator of nuclear factor- $\mathrm{\kappa} B$ (NF-кB) ligand (RANKL; $50 \mathrm{ng} / \mathrm{ml}$ ) for $96 \mathrm{~h}$. The osteoclastic cells formed were further cultured for 24 or $72 \mathrm{~h}$ in a medium containing either vehicle, CRP, zinc sulfate (zinc), or CRP plus zinc with or without M-CSF $(10 \mathrm{ng} / \mathrm{ml})$ and RANKL (50 ng/ml). The number of osteoclastic cells was significantly decreased after culture with the combination of CRP $\left(10^{-7} \mathrm{M}\right)$ and zinc $\left(10^{-5} \mathrm{M}\right)$ in the presence or absence of M-CSF and RANKL for 24 or $72 \mathrm{~h}$ as compared with the value for CRP or zinc alone. Agarose gel electrophoresis showed the presence of low-molecular weight deoxyribonucleic acid (DNA) fragments of adherent cells cultured with CRP $\left(10^{-7} \mathrm{M}\right)$ plus zinc $\left(10^{-5} \mathrm{M}\right)$ for 24 or $72 \mathrm{~h}$ in the presence of M-CSF and RANKL, indicating that the combination of the two chemicals induces apoptotic cell death. CRP plus zinc-induced decrease in osteoclastic cells was significantly inhibited in the presence of caspase- 3 inhibitor $\left(10^{-8}\right.$ or $\left.10^{-7} \mathrm{M}\right)$. Culture with CRP $\left(10^{-7} \mathrm{M}\right)$ plus zinc $\left(10^{-5} \mathrm{M}\right)$ for 24 or $72 \mathrm{~h}$ caused a significant increase in caspase-3 mRNA expression in the presence or absence of M-CSF and RANKL as compared with the value for each chemical alone. CRP plus zinc-induced increase in caspase- 3 mRNA expression was completely inhibited in the presence of cycloheximide $\left(10^{-7} \mathrm{M}\right)$, an inhibitor of protein synthesis, or 5,6-dichloro-1-ß-D-ribo-
\end{abstract}

Correspondence to: Dr Masayoshi Yamaguchi, ${ }^{2}$ Present address: Division of Endocrinology and Metabolism and Lipids, Department of Medicine, Emory University School of Medicine, 1639 Pierce Drive, 1305 WMRB, Atlanta, GA 30322-0001, USA

E-mail: yamamasa1155@yahoo.co.jp

Key words: ß-cryptoxanthin, zinc, osteoclastogenesis, apoptosis, gene expression furanosylbenzimidazole (DBR; $10^{-6} \mathrm{M}$ ), an inhibitor of transcription activity. The mRNA expression of tartrateresistant acid phosphatase (TRACP) and cathepsin K was significantly decreased after culture with CRP plus zinc in the presence or absence of M-CSF and RANKL for $72 \mathrm{~h}$ as compared with CRP or zinc alone. Nuclear factor of activated T cells c1 (NFATc1) mRNA expression was significantly decreased after culture with CRP plus zinc in the presence or absence of M-CSF and RANKL for $72 \mathrm{~h}$ as compared with each chemical alone, while NF-кB mRNA expression was not significantly changed. This study demonstrated that the combination of CRP and zinc has potent suppressive effects on osteoclastic cells in vitro.

\section{Introduction}

Osteoporosis and its related fractures represent major public health problems that are expected to increase dramatically as the population ages. Bone loss with aging induces osteoporosis. Bone loss may be due to decreased bone formation and increased bone resorption. Food and nutritional factors may help to prevent bone loss with increasing age $(1,2)$.

ß-Cryptoxanthin (CRP), a kind of carotenoid, has unique anabolic effects on bone calcification in vitro $(3,4)$; lutein, lycopene, $\beta$-carotene, and astaxanthin, which are carotenoids, do not have an effect on bone calcification in rat femoral tissue culture in vitro. CRP has direct stimulatory effects on osteoblastic bone formation $(5,6)$ and inhibitory effects on osteoclastic bone resorption in vitro $(7,8)$. Oral administration of CRP prevents bone loss in ovariectomized rats, an animal model of osteoporosis (9), suggesting that CRP has preventive effects on osteoporosis with aging.

Zinc is known to be an essential trace element for the growth of humans and other animals $(10,11)$. Zinc deficiency results in a retardation of bone growth $(12,13)$, suggesting that the element is required for the growth, development, and maintenance of healthy bone. Zinc has been shown to stimulate osteoblastic bone formation $(14,15)$ and inhibit osteoclastic bone resorption (15-17). The pathophysiologic role of zinc in osteopenia and osteoporosis has also been shown. Bone zinc content is reduced with aging and skeletal unloading in rats $(18,19)$. Osteoporosis patients have been shown to have lower levels of skeletal zinc than normal individuals (20). Women with osteoporosis excrete a great 
amount of zinc in urine (21). The oral administration of zinc compound has been shown to have preventive effects on bone loss in ovariectomized rats (22). Zinc may play a role in the prevention of osteoporosis with aging (19).

The anabolic effect of CRP on bone components in rat femoral tissues has been shown to enhance synergistically with zinc treatment in vitro (23) and in vivo (24). The combination of CRP and zinc may have a potent preventive effect on bone loss with aging. However, the cellular mechanism by which the combination of CRP and zinc has synergisticanabolic effects on bone metabolism has not yet been clarified.

This study was undertaken to determine whether zinc modulates the suppressive effects of CRP on osteoclastic cells in vitro. We found that zinc enhances the stimulatory effects of CRP on apoptotic cell death and the suppressive effects of CRP on the gene expression of various molecules related to bone resorption in osteoclastic cells.

\section{Materials and methods}

Chemicals. $\alpha$-minimal essential medium ( $\alpha$-MEM) and penicillin-streptomycin $(5000 \mathrm{U} / \mathrm{ml}$ penicillin; $5000 \mu \mathrm{g} / \mathrm{ml}$ streptomycin) were obtained from Gibco Laboratories (Grand Island, NY). Fetal bovine serum (FBS), cycloheximide, 5,6-dichloro-1- $\beta$-D-ribofuranosylbenzimidazole (DRB), macrophage colony-stimulating factor (M-CSF, mouse), and receptor activator of NF- $\mathrm{KB}$ ligand (RANKL, mouse) were obtained from Sigma (St. Louis, MO). B-cryptoxanthin (CRP) was obtained from Extrasynthase (Lyon-Nord, France). Caspase-3/CPP 32 inhibitor W-1 (caspase-3 inhibitor), zinc sulfate, and other chemicals were obtained from Wako Pure Chemical Industries (Osaka, Japan). All water used was glass distilled.

Animals. Female mice (ddY strain; 6 weeks old) were obtained from Japan SLC (Hamamatsu, Japan). The animals were fed commercial laboratory chow (solid) containing $1.1 \%$ calcium, $1.1 \%$ phosphorus and $0.012 \%$ zinc, and given distilled water. Mice were sacrificed by exsanguination.

Marrow culture and osteoclast differentiation. Bone marrow cells were isolated from mice for studies on primary osteoclast precursor, as reported elsewhere (25). Briefly, the bone ends of the femur were cut off, and the marrow cavity was flushed with $1 \mathrm{ml}$ of $\alpha$-MEM. The marrow cells were washed with $\alpha$-MEM and cultured in the same medium containing $10 \%$ heat-inactivated fetal bovine serum M-CSF $(10 \mathrm{ng} / \mathrm{ml}$ of medium) at $1.5 \times 10^{7}$ cells $/ \mathrm{ml}$ in 24-well plates $(0.5 \mathrm{ml} / \mathrm{well})$ in a water-saturated atmosphere containing $5 \% \mathrm{CO}_{2}$ and $95 \%$ air at $37^{\circ} \mathrm{C}$. After 2 days, adherent cells were used as the M-CSFdependent bone marrow macrophage (M-BMM) after washing out the non-adherent cells, including lymphocytes. The cells were then cultured in the presence of M-CSF $(10 \mathrm{ng} / \mathrm{ml})$ and RANKL (50 ng/ml) for 4 days to generate mature osteoclasts. The purity of the osteoclastic cell preparation was usually in the range of $85-95 \%$ estimating tartrate-resistant acid phosphatase (TRACP) activity.

To determine the effect of CRP or zinc in the cell death and apoptosis of mature osteoclasts, they were incubated for 24 or $72 \mathrm{~h}$ in medium containing either vehicle (1\% ethanol),
B-cryptoxanthin $\left(10^{-8}\right.$ or $\left.10^{-7} \mathrm{M}\right)$, or zinc sulfate $\left(10^{-6}\right.$ or $\left.10^{-5} \mathrm{M}\right)$ in the presence or absence of M-CSF $(10 \mathrm{ng} / \mathrm{ml})$ and RANKL (50 ng/ml).

Enzyme histochemistry. After culture, cells adherent to 24-well plates were stained for TRACP, a marker enzyme of osteoclasts $(26,27)$. Briefly, the cells were washed with Hanks' balanced salt solution and fixed with $10 \%$ neutralized formalin-phosphate ( $\mathrm{pH}$ 7.2) for $10 \mathrm{~min}$. After the culture dishes were dried, TRACP staining was applied according to the method of Burstone (26). The fixed cells were incubated for $12 \mathrm{~min}$ at room temperature $\left(25^{\circ} \mathrm{C}\right)$ in acetate buffer $(\mathrm{pH} 5.0)$ containing naphthol AS-MX phosphate (Sigma) as a substrate, and red violet LB salt (Sigma) as a stain for the reaction product in the presence of $10 \mathrm{mM}$ sodium tartrate. TRACP-positive multinucleated cells (MNCs) containing three or more nuclei were counted as osteoclast-like cells.

Analysis of DNA fragmentation. The osteoclastic cells formed were cultured for 24 or $72 \mathrm{~h}$ in a medium containing either vehicle, CRP $\left(10^{-7} \mathrm{M}\right)$, zinc $\left(10^{-5} \mathrm{M}\right)$, or CRP $\left(10^{-7} \mathrm{M}\right)$ plus zinc $\left(10^{-5} \mathrm{M}\right)$ with or without M-CSF $(10 \mathrm{ng} / \mathrm{ml})$ and RANKL (50 ng/ml). The culture supernatant was removed, and adherent cells were than lysed in $10 \mathrm{mM}$ Tris-HCl, $\mathrm{pH} 2.4$, $10 \mathrm{mM}$ EDTA (neutralized), and $0.5 \%$ Triton X-100. Lowmolecular weight DNA fragments were separated by electrophoresis in $1.5 \%$ agarose gel (28). The gels were visualized by ethidium bromide staining with an UV transilluminator (Funakoshi Co. Ltd., Tokyo, Japan). The DNA content in the cell lysate was determined by the method of Ceriotti (29).

Determination of specific mRNA by RT-PCR. Total RNAs were prepared as described previously (30). After the M-BMM were cultured in $\alpha$-MEM containing $0.5 \%$ FBS for $24 \mathrm{~h}$ and were further cultured in the presence of M-CSF $(10 \mathrm{ng} / \mathrm{ml})$ and RANKL $(25 \mathrm{ng} / \mathrm{ml})$, the generated osteoclasts were cultured for 24 or $72 \mathrm{~h}$ in a medium containing either vehicle, CRP $\left(10^{-7} \mathrm{M}\right)$, zinc $\left(10^{-5} \mathrm{M}\right)$, or CRP $\left(10^{-7} \mathrm{M}\right)$ plus zinc $\left(10^{-5} \mathrm{M}\right)$. After culture, the cells were washed three times with ice-cold PBS, and were then homogenized in buffer solution containing $4 \mathrm{M}$ guanidinium thiocyanate, $24 \mathrm{mM}$ sodium citrate ( $\mathrm{pH} 7.0), 0.5 \%$ sarcosyl, and isoamyl alcohol, and the phases were separated by centrifugation at $10,000 \mathrm{x}$ g for $20 \mathrm{~min}$ at $4^{\circ} \mathrm{C}$. RNA located in the aqueous phase was precipitated with isoprepanol at $-20^{\circ} \mathrm{C}$. RNA precipitates were pelleted by centrifugation, and the pellets were redissolved in diethylpyrocarbonate-treated water.

Reverse transcription-polymerase chain reaction (RT-PCR) was preformed with a Titan ${ }^{\mathrm{TM}}$ One Tube RT-PCR kit (Roche Molecular Biochemicals) as recommended by the supplier. The primers for amplification of mouse caspase- 3 cDNA were: 5'-GCTCTGGTACGGATGTGGACGCA-3' (sense strand, positions 254-276 of cDNA sequence) and 5'-CTC AATGCCACAGTCCAGCTCCG-3' (antisense strand, positions 560-582) (31). The pair of oligonucleotide primers was designed to amplify a 329-bp sequence from the mRNA of mouse caspase- 3 .

Primers for the amplification of mouse TRACP cDNA were: 5'-CAACGGCTACTTGCGGTTTC-3' (sense strand, positions 963-982 of cDNA sequence) and 5'-TGTGGGATC 
AGTTGGTGTGG-3' (antisense strand, positions 1,281-1,300) (32). The pair of oligonucleotide primers was designed to amplify a 388-bp sequence from the mRNA of mouse TRACP.

Primers for the amplification of mouse cathepsin cDNA were: 5'-CAGCAGGATGTGGGTGTTCA-3' (sense strand, positions 47-66 of cDNA sequence) and 5'-ACACTGGC CCTGGTTCTTGA-3' (antisense strand, positions 442-261) (33). The pair of oligonucleotide primers was designed to amplify a 415-bp sequence from the mRNA of mouse cathepsin $\mathrm{K}$.

Primers for the amplification of mouse NFATc1 cDNA were: 5'-GGCGAAGCCCAAGTCTCTTT-3' (sense strand, positions 1,484-1,503 of cDNA sequence) and 5'-ACCACCA GCCACGAGATCAT-3' (antisense strand, positions 18051824) (34). The pair of oligonucleotide primers was designed to amplify a 341-bp sequence from the mRNA of mouse NFATc1. Primers for the amplification of mouse NF-кB cDNA were: 5'-TCCACGAGGCAGCACATAGA-3' (sense strand, positions 3,028-3,047 of cDNA sequence) and 5'-CCA AAGGTGCTGGAGAATCG-3' (antisense strand, positions 3,291-3,310) (35).

The pair of oligonucleotide primers was designed to amplify a 283-bp sequence from the mRNA of mouse NF- $\mathrm{BB}$ cDNA. Glyceraldehyde-3-phosphate dehydrogenase (G3PDH) was used as an internal control to evaluate total RNA input.

Primers for the amplification of G3PDH cDNA were: 5'-GATTTGGCCGTATCGGACGC-3' (sense strand) and 5'-CTCCTTGGAGGCCATGTAGG-3' (antisense strand). The pair of oligonucleotide primers was designed to amplify a 977-bp sequence from the mRNA of rat G3PDH.

RT-PCR was performed using a reaction mixture $(20 \mu \mathrm{l})$ containing $2 \mu \mathrm{g}$ of total RNAs, supplied RT-PCR buffer, Titan $^{\mathrm{TM}}$ enzyme mix (AMV and Expand ${ }^{\mathrm{TM}}$ High Fidelity), $0.2 \mathrm{mM}$ dNTP, $5 \mathrm{mM}$ dithiothreitol, $5 \mathrm{U}$ RNase inhibitor, and $0.3 \mathrm{mM}$ primers. Samples were incubated at $50^{\circ} \mathrm{C}$ for $30 \mathrm{~min}$, and then amplified for 35 cycles under the following conditions: denaturation for $30 \mathrm{sec}$ at $94^{\circ} \mathrm{C}$, annealing for $30 \mathrm{sec}$ at $56^{\circ} \mathrm{C}$, and extension for $60 \mathrm{sec}$ at $68^{\circ} \mathrm{C}$. The amplified products were separated by electrophoresis on a $1.5 \%$ agarose gel and were visualized by ethidium bromide staining. Image density was quantified with a FluoroImager SI (Amersham Pharmacia Biotech).

Statistical analysis. Data are expressed as the mean \pm SEM. Statistical differences were analyzed using a Student's t-test. P-values $<0.05$ were considered to indicate a statistically significant difference. An ANOVA multiple comparison test was also used to compare the treatment groups.

\section{Results}

Effect on osteoclastic apoptosis. The effects of CRP or zinc on osteoclastic cells, induced in the presence or absence of M-CSF and RANKL in the mouse marrow culture were examined. Osteoclastic cells were cultured in a medium containing either vehicle (1\% ethanol), CRP $\left(10^{-8}\right.$ or $\left.10^{-7} \mathrm{M}\right)$, zinc $\left(10^{-6}\right.$ or $\left.10^{-5} \mathrm{M}\right)$, CRP $\left(10^{-8} \mathrm{M}\right)$ plus zinc $\left(10^{-6} \mathrm{M}\right)$, or CRP $\left(10^{-7} \mathrm{M}\right)$ plus zinc $\left(10^{-5} \mathrm{M}\right)$ in the absence (Fig. 1) or presence

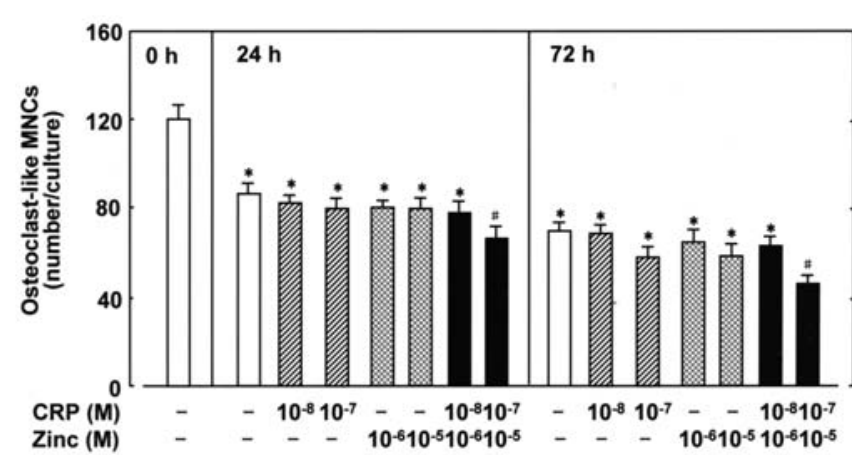

Figure 1. Effect of $\beta$-cryptoxanthin (CRP) and/or zinc on osteoclastic cell death in the absence of M-CSF and RANKL in mouse marrow culture. Mouse marrow cells were cultured as described in Materials and methods. The adherent cells were cultured for $96 \mathrm{~h}$ in a medium containing $0.5 \%$ FBS, M-CSF (10 ng/ml), and RANKL (50 ng/ml). After medium change, the TRACP-positive MNCs formed were cultured for 24 or $72 \mathrm{~h}$ in a medium containing either vehicle $\left(1 \%\right.$ ethanol), CRP $\left(10^{-8}\right.$ or $\left.10^{-7} \mathrm{M}\right)$, zinc $\left(10^{-6}\right.$ or $\left.10^{-5} \mathrm{M}\right)$, or CRP $\left(10^{-8} \mathrm{M}\right)$ plus zinc $\left(10^{-6} \mathrm{M}\right)$, or CRP $\left(10^{-7} \mathrm{M}\right)$ plus zinc $\left(10^{-5} \mathrm{M}\right)$ in the absence of M-CSF $(10 \mathrm{ng} / \mathrm{ml})$ plus RANKL $(50 \mathrm{ng} / \mathrm{ml})$. The cells were then fixed and stained for TRACP, and the number of TRACP-positive MNCs was scored. Each value is the mean \pm SEM of six cultures. ${ }^{*} \mathrm{P}<0.01$ compared with the control (none) value at zero time. ${ }^{\#} \mathrm{P}<0.01$ compared with the value for CRP or zinc alone.

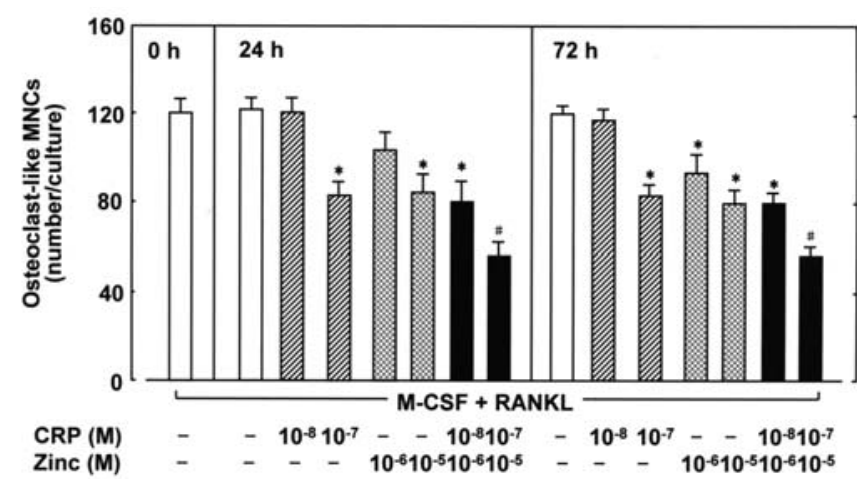

Figure 2. Effect of ß-cryptoxanthin (CRP) and/or zinc on osteoclastic cell death in the presence of M-CSF and RANKL in mouse marrow culture. Osteoclasts were cultured as described in the legend for Fig. 1. The osteoclastic cells were cultured for 24 or $72 \mathrm{~h}$ in a medium containing either vehicle ( $1 \%$ ethanol), CRP $\left(10^{-8}\right.$ or $\left.10^{-7} \mathrm{M}\right)$, zinc $\left(10^{-6}\right.$ or $\left.10^{-5} \mathrm{M}\right)$, or CRP $\left(10^{-8} \mathrm{M}\right)$ plus zinc $\left(10^{-6} \mathrm{M}\right)$, or CRP $\left(10^{-7} \mathrm{M}\right)$ plus zinc $\left(10^{-5} \mathrm{M}\right)$ in the presence of M-CSF plus RANKL. The cells were then fixed and stained for TRACP, and the number of TRACP-positive MNCs was scored. Each value is the mean \pm SEM of six cultures. ${ }^{*} \mathrm{P}<0.01$ compared with the control (none) value at zero time. ${ }^{\mathrm{P}}<0.01$ compared with the control value at 24 or $72 \mathrm{~h}$.

(Fig. 2) of M-CSF (10 ng/ml) and RANKL (50 ng/ml) for 24 or $72 \mathrm{~h}$. Osteoclastic cells were significantly decreased after culture for 24 or $72 \mathrm{~h}$ in the absence of M-CSF and RANKL as compared with the value obtained at the zero time (Fig. 1). The number of osteoclastic cells was significantly decreased after culture with CRP $\left(10^{-7} \mathrm{M}\right)$ plus zinc $\left(10^{-5} \mathrm{M}\right)$ for 24 or $72 \mathrm{~h}$ as compared with the value obtained from CRP $\left(10^{-7} \mathrm{M}\right)$ or zinc $\left(10^{-5} \mathrm{M}\right)$ alone.

In the presence of M-CSF (10 ng/ml) and RANKL (50 $\mathrm{ng} / \mathrm{ml}$ ) for 24 or $72 \mathrm{~h}$, the osteoclastic cells formed were not significantly decreased as compared with the value obtained at the zero time (Fig. 2). The number of osteoclast-like cells 


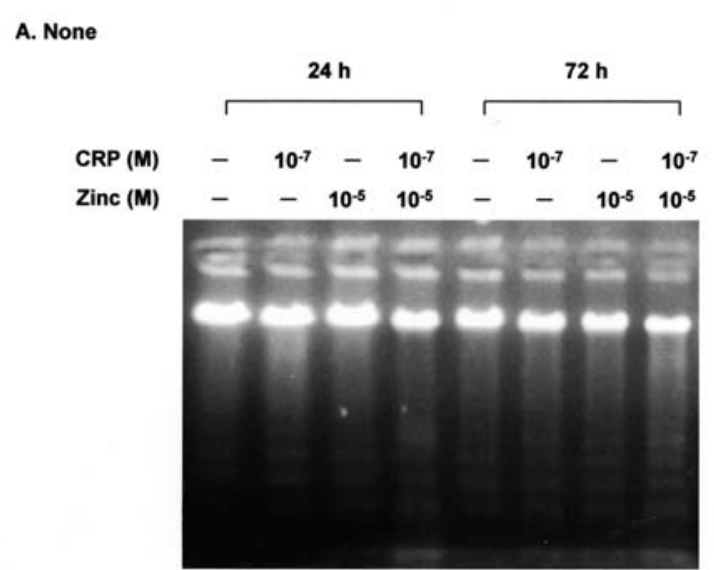

\section{B. M-CSF+RANKL}

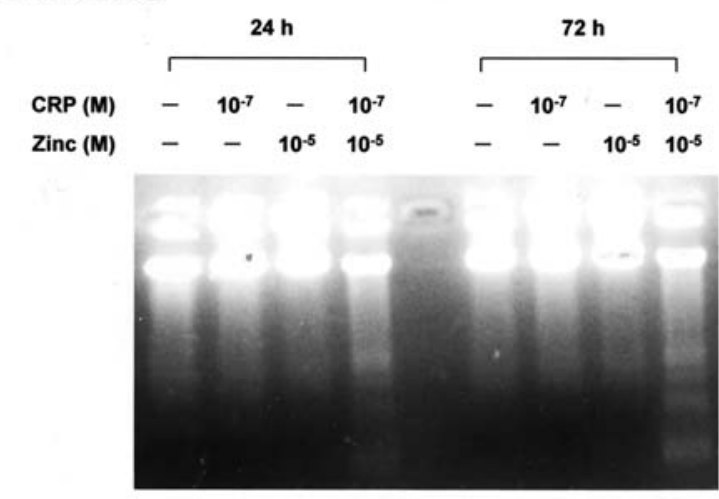

Figure 3. Effect of ß-cryptoxanthin (CRP) and/or zinc on DNA fragmentation in osteoclastic cells formed in mouse marrow culture. Osteoclasts were cultured as described in the legend for Fig. 1. The osteoclastic cells were cultured for 24 or $72 \mathrm{~h}$ in a medium containing either vehicle ( $1 \%$ ethanol), CRP $\left(10^{-7} \mathrm{M}\right)$, zinc $\left(10^{-6} \mathrm{M}\right)$ or a combination, in the absence (A) or presence (B) of M-CSF $(10 \mathrm{ng} / \mathrm{ml})$ plus RANKL $(50 \mathrm{ng} / \mathrm{ml})$, and the lysate (containing $2 \mu \mathrm{g}$ DNA) of adherent cells was applied to agarose gel. The figure shows one of four experiments with separate samples.

was significantly decreased after culture with CRP $\left(10^{-7} \mathrm{M}\right)$, zinc $\left(10^{-5} \mathrm{M}\right)$, or CRP $\left(10^{-8} \mathrm{M}\right)$ plus zinc $\left(10^{-6} \mathrm{M}\right)$. Culture with CRP $\left(10^{-7} \mathrm{M}\right)$ plus zinc $\left(10^{-5} \mathrm{M}\right)$ for 24 or $72 \mathrm{~h}$ caused a significant decrease in osteoclast-like cells as compared with the value obtained from CRP $\left(10^{-7} \mathrm{M}\right)$ or zinc $\left(10^{-5} \mathrm{M}\right)$ alone in the presence of M-CSF and RANKL.

The effects of CRP or zinc on DNA fragmentation in osteoclastic cells formed with culture in the absence (Fig. 3A) or presence (Fig. 3B) of M-CSF and RANKL was examined. Osteoclastic cells were cultured for 24 or $72 \mathrm{~h}$ in a medium containing either vehicle (1\% ethanol), CRP $\left(10^{-7} \mathrm{M}\right)$, zinc $\left(10^{-5} \mathrm{M}\right)$, or CRP $\left(10^{-7} \mathrm{M}\right)$ plus zinc $\left(10^{-5} \mathrm{M}\right)$ in the presence or absence of M-CSF (10 ng/ml) and RANKL (50 ng/ml). The adherent cells were lysed, and then the lysate was separated by electrophoresis in agarose gel. Culture with CRP plus zinc caused DNA fragmentation in the presence of M-CSF and RANKL (Fig. 3B).

The effect of caspase- 3 inhibitor on the CRP plus zincinduced cell death was examined (Fig. 4). The adherent cells were cultured for $96 \mathrm{~h}$ in a medium containing M-CSF

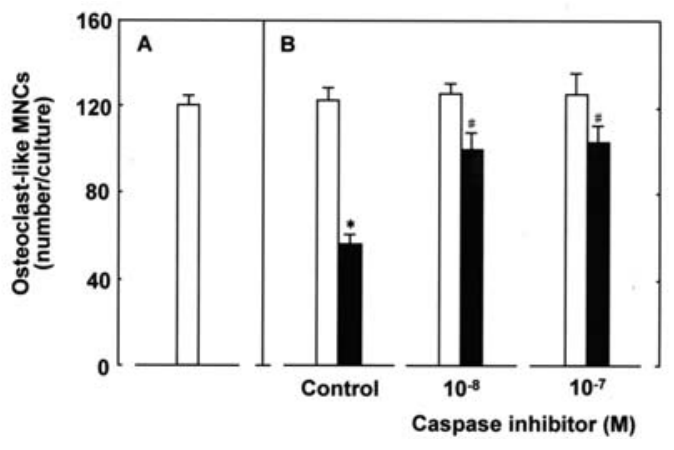

Figure 4. Effect of ß-cryptoxanthin (CRP) plus zinc in the presence of caspase-3 inhibitor on osteoclastic cells formed in mouse marrow culture. Osteoclasts were cultured as described in the legend to Fig. 1. The adherent cells were cultured for $96 \mathrm{~h}$ in medium containing $0.5 \% \mathrm{FBS}, \mathrm{M}-\mathrm{CSF}$ $(10 \mathrm{ng} / \mathrm{ml})$, and RANKL $(50 \mathrm{ng} / \mathrm{ml})$, and the number of osteoclastic cells was measured (A). After medium change, the osteoclast cells were cultured for $24 \mathrm{~h}$ in medium containing either vehicle $\left(1 \%\right.$ ethanol) or CRP $\left(10^{-7} \mathrm{M}\right)$ plus zinc $\left(10^{-5} \mathrm{M}\right)$ with or without caspase-3 inhibitor $\left(10^{-8}\right.$ or $\left.10^{-7} \mathrm{M}\right)$ in the presence of M-CSF (10 ng/ml) plus RANKL (50 ng/ml) (B). The cells were then fixed and stained for TRACP, and the number of TRACP-positive MNCs was scored. Each value is the mean \pm SEM of six cultures. ${ }^{*} \mathrm{P}<0.01$ compared with the control (none) value with or without caspase- 3 inhibitor. ${ }^{\#} \mathrm{P}<0.01$ compared with the value for CRP plus zinc without caspase-3 inhibitor. (B) White bars, without CRP plus zinc; black bars, with CRP plus zinc.

(10 ng/ml) and RANKL (50 ng/ml) (Fig. 4A). The osteoclastic cells formed were cultured for $72 \mathrm{~h}$ in a medium containing either vehicle $\left(1 \%\right.$ ethanol) or CRP $\left(10^{-7} \mathrm{M}\right)$ plus zinc $\left(10^{-5} \mathrm{M}\right)$ with or without caspase- 3 inhibitor $\left(10^{-8}\right.$ or $\left.10^{-7} \mathrm{M}\right)$ in the presence of M-CSF $(10 \mathrm{ng} / \mathrm{ml})$ and RANKL $(50 \mathrm{ng} / \mathrm{ml})$ (Fig. 4B). The CRP plus zinc-induced decrease in osteoclastic cells was significantly inhibited after culture with caspase- 3 inhibitor $\left(10^{-8}\right.$ or $\left.10^{-7} \mathrm{M}\right)$ as compared with the value obtained in the presence of CRP plus zinc without caspase-3 inhibitor (Fig. 4B).

Effect on caspase-3 mRNA expression in osteoclastic cells. The effects of CRP or zinc on caspase- 3 mRNA expression in osteoclastic cells were examined (Fig. 5). Osteoclastic cells were cultured in a medium containing either vehicle (1\% ethanol), CRP $\left(10^{-7} \mathrm{M}\right)$, zinc $\left(10^{-5} \mathrm{M}\right)$, or CRP $\left(10^{-7} \mathrm{M}\right)$ plus zinc $\left(10^{-5} \mathrm{M}\right)$ in the presence or absence of M-CSF $(10 \mathrm{ng} / \mathrm{ml})$ and RANKL $(50 \mathrm{ng} / \mathrm{ml})$ for 24 or $72 \mathrm{~h}$. Culture with CRP $\left(10^{-7} \mathrm{M}\right)$ or zinc $\left(10^{-5} \mathrm{M}\right)$ in the presence or absence of M-CSF and RANKL for 24 or $72 \mathrm{~h}$ caused a significant increase in caspase- 3 mRNA expression in osteoclastic cells. Caspase-3 mRNA expression was synergistically enhanced after culture with the combination of CRP $\left(10^{-7} \mathrm{M}\right)$ and zinc $\left(10^{-5} \mathrm{M}\right)$ in the presence or absence of M-CSF and RANKL for 24 or $72 \mathrm{~h}$ as compared with that of each factor alone (Fig. 5A). G3PDH mRNA expression was not significantly changed in osteoclastic cells cultured in the presence of CRP $\left(10^{-7} \mathrm{M}\right)$, zinc $\left(10^{-5} \mathrm{M}\right)$, or CRP $\left(10^{-7} \mathrm{M}\right)$ plus zinc $\left(10^{-5} \mathrm{M}\right)$ with or without M-CSF and RANKL (Fig. 5B).

The effects of cycloheximide or DBR on the CRP plus zinc-induced increase in caspase- 3 mRNA expression in osteoclastic cells were examined (Fig. 6). The CRP $\left(10^{-7} \mathrm{M}\right)$ plus zinc $\left(10^{-5} \mathrm{M}\right)$-induced increase in caspase-3 mRNA 
A. Caspase-3

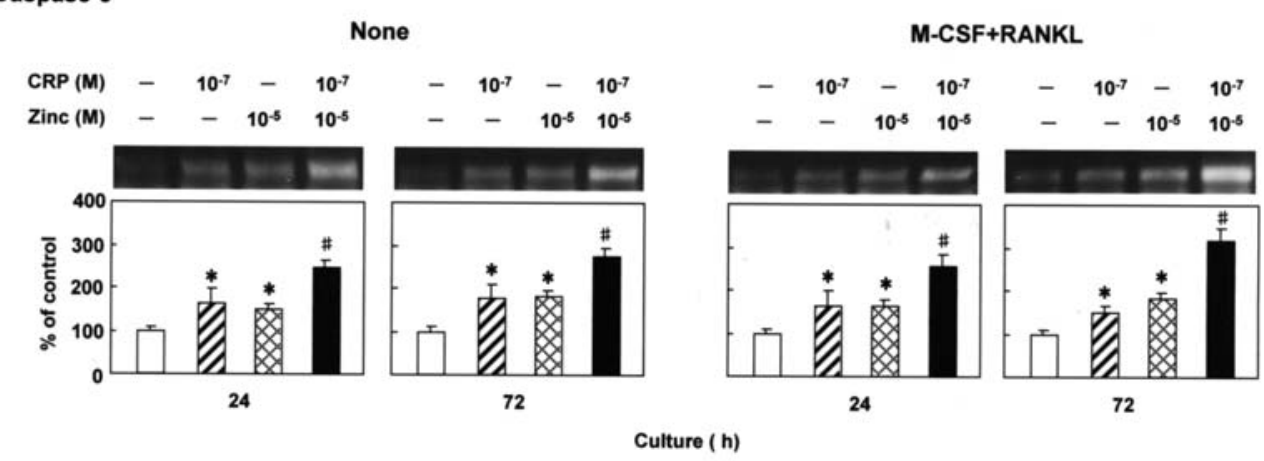

B. G3PDH

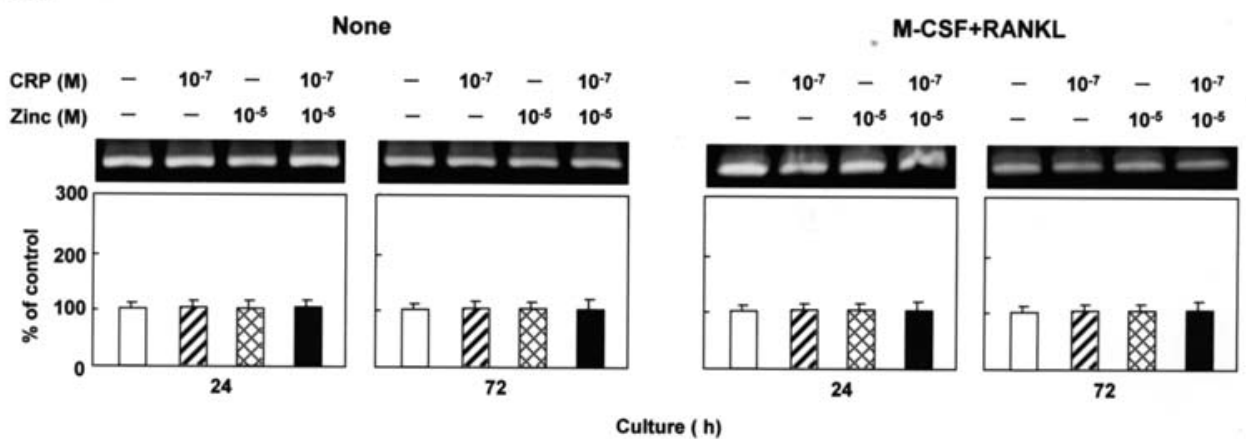

Figure 5. Effect of B-cryptoxanthin (CRP) and/or zinc on the mRNA expression of caspase-3 (A) and G3PDH (B) in osteoclastic cells formed in mouse marrow culture. Osteoclasts were cultured as described in the legend for Fig. 1. The osteoclastic cells were cultured for 24 or $72 \mathrm{~h}$ in medium containing either vehicle $\left(1 \%\right.$ ethanol), CRP $\left(10^{-7} \mathrm{M}\right)$, zinc $\left(10^{-5} \mathrm{M}\right)$, or CRP $\left(10^{-7} \mathrm{M}\right)$ plus zinc $\left(10^{-5} \mathrm{M}\right)$ in the presence or absence of M-CSF $(10$ ng/ml $)$ plus RANKL $(50 \mathrm{ng} / \mathrm{ml})$. Total RNAs $(2 \mu \mathrm{g})$ extracted from the adherent cells were analyzed by RT-PCR using specific primers. The figure shows one of five experiments with separate samples. The densitometric data for each mRNA level were indicated as $\%$ of control (mean \pm SEM of five experiments). ${ }^{*}<0.01$ compared with the control (none) value.

expression was not seen in osteoclastic cells cultured with cycloheximide $\left(10^{-7} \mathrm{M}\right)$ (Fig. 6A), an inhibitor of protein synthesis, or DRB ( $\left.10^{-6} \mathrm{M}\right)$ (Fig. 6B), an inhibitor of transcriptional activity, in the presence or absence of M-CSF (10 ng/ml) and RANKL (50 ng/ml). G3PDH mRNA expression was not significantly changed in this experiment (data not shown).

Effect on bone resorption-related gene expression in osteoclastic cells. The effects of CRP or zinc on the mRNA expression of TRACP or cathepsin $\mathrm{K}$ related to osteoclastic bone resorption were examined (Fig. 7). The expression of TRACP mRNA was significantly decreased in osteoclastic cells cultured with CRP $\left(10^{-7} \mathrm{M}\right)$ plus zinc $\left(10^{-5} \mathrm{M}\right)$ in the presence or absence of M-CSF (10 ng/ml) and RANKL (50 ng/ml) for $72 \mathrm{~h}$ (Fig. 7A). CRP $\left(10^{-7} \mathrm{M}\right)$ or zinc $\left(10^{-5} \mathrm{M}\right)$ alone did not have a significant effect on TRACP mRNA expression in osteoclastic cells with or without M-CSF and RANKL.

Cathepsin K mRNA expression in osteoclastic cells was significantly decreased after culture with zinc $\left(10^{-5} \mathrm{M}\right)$ in the presence or absence of M-CSF $(10 \mathrm{ng} / \mathrm{ml})$ and RANKL $(50 \mathrm{ng} / \mathrm{ml})$ for $72 \mathrm{~h}$ (Fig. 7B). Culture with CRP $\left(10^{-7} \mathrm{M}\right)$ did not cause a significant change in cathepsin $\mathrm{K}$ mRNA expression with or without M-CSF and RANKL. The combination of CRP $\left(10^{-7} \mathrm{M}\right)$ plus zinc $\left(10^{-5} \mathrm{M}\right)$ had a synergisticsuppressive effect on cathepsin $\mathrm{K}$ mRNA expression in osteoclastic cells cultured with M-CSF and RANKL for 24 or 72 h (Fig. 7B).
Effect on RANKL signaling-related gene expression in osteoclastic cells. The effects of CRP or zinc on the mRNA expression of NF- $\mathrm{KB}$ or NFATc1, related to RANKL signaling, in osteoclastic cells, were examined (Fig. 8). NF- $\kappa$ B mRNA expression in osteoclastic cells was not significantly changed after culture with CRP $\left(10^{-7} \mathrm{M}\right)$, zinc $\left(10^{-5} \mathrm{M}\right)$, or CRP $\left(10^{-7} \mathrm{M}\right)$ plus zinc $\left(10^{-5} \mathrm{M}\right)$ in the presence or absence of M-CSF $(10 \mathrm{ng} / \mathrm{ml})$ and RANKL $(50 \mathrm{ng} / \mathrm{ml})$ for 24 or $72 \mathrm{~h}$ (Fig. 8A).

NFATc1 mRNA expression in osteoclastic cells was significantly changed after culture with CRP $\left(10^{-7} \mathrm{M}\right)$ or zinc $\left(10^{-5} \mathrm{M}\right)$ in the absence of M-CSF (10 ng/ml) plus RANKL $(50 \mathrm{ng} / \mathrm{ml})$ for 24 or $72 \mathrm{~h}$ (Fig. 8B). Culture with CRP $\left(10^{-7} \mathrm{M}\right)$ plus zinc $\left(10^{-5} \mathrm{M}\right)$ caused a significant decrease in NFATc1 mRNA expression in osteoclastic cells cultured without M-CSF and RANKL for $72 \mathrm{~h}$. In the presence of M-CSF and RANKL, NFATc1 mRNA expression was not significantly changed in osteoclastic cells cultured with CRP $\left(10^{-7} \mathrm{M}\right)$ for 24 or $72 \mathrm{~h}$, while it was significantly decreased after culture with zinc $\left(10^{-5} \mathrm{M}\right)$ for $72 \mathrm{~h}$ but not $24 \mathrm{~h}$. Culture with CRP $\left(10^{-7} \mathrm{M}\right)$ plus zinc $\left(10^{-5} \mathrm{M}\right)$ caused a significant decrease in NFATc1 mRNA expression in osteoclastic cells cultured in the presence or absence of M-CSF and RANKL for $72 \mathrm{~h}$. Such an effect was also seen in osteoclastic cells cultured in the presence of M-CSF and RANKL for $24 \mathrm{~h}$.

G3PDH mRNA expression was not significantly changed in osteoclastic cells cultured in the presence of CRP $\left(10^{-7} \mathrm{M}\right)$, zinc $\left(10^{-5} \mathrm{M}\right)$, or CRP $\left(10^{-7} \mathrm{M}\right)$ plus zinc $\left(10^{-5} \mathrm{M}\right)$ with or without M-CSF and RANKL, as shown in Fig. 5B. 


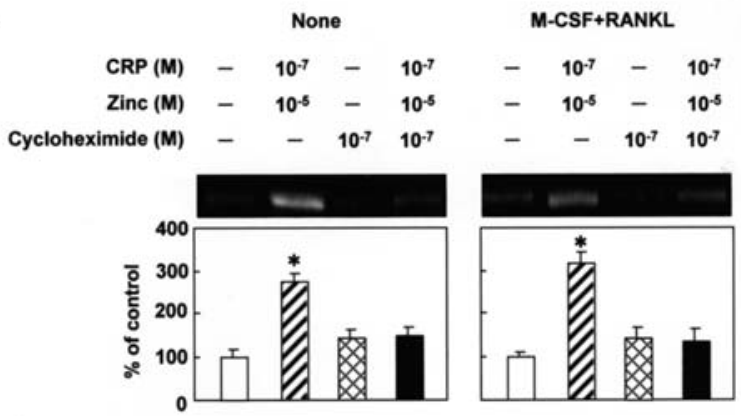

B

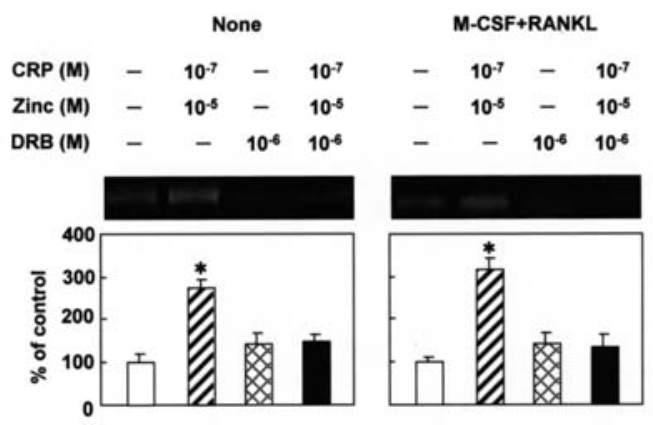

Figure 6. Effect of cycloheximide (A) or DBR (B) on the B-cryptoxanthin (CRP) and zinc-stimulated caspase-3 mRNA expression in osteoclastic cells formed in mouse marrow culture. Osteoclasts were cultured as described in the legend for Fig. 1. The osteoclastic cells were cultured for $72 \mathrm{~h}$ in medium containing either vehicle ( $1 \%$ ethanol), CRP $\left(10^{-7} \mathrm{M}\right)$, zinc $\left(10^{-5} \mathrm{M}\right)$, or CRP $\left(10^{-7} \mathrm{M}\right)$ plus zinc $\left(10^{-5} \mathrm{M}\right)$ with or without cycloheximide $\left(10^{-7} \mathrm{M}\right)$ or DRB $\left(10^{-6} \mathrm{M}\right)$ in the presence or absence of M-CSF $(10 \mathrm{ng} / \mathrm{ml})$ plus RANKL $(50 \mathrm{ng} / \mathrm{ml})$. Total RNAs $(2 \mu \mathrm{g})$ extracted from the adherent cells were analyzed by RT-PCR using specific primers. The figure shows one of five experiments with separate samples. The densitometric data for each mRNA levels were indicated as \% of control (mean \pm SEM of five experiments). ${ }^{*} \mathrm{P}<0.01$ compared with the control (none) value.

\section{Discussion}

The anabolic effect of $\beta$-cryptoxanthin (CRP) on bone components in rat femoral tissues has been shown to enhance synergistically with zinc treatment in vitro (23) and in vivo (24). The cellular mechanism by which the combination of CRP and zinc has a synergistic-anabolic effect on bone metabolism has not been yet clarified. We found that the combination of CRP and zinc has potent stimulatory effects on cell death and suppressive effects on gene expression related to bone resorption in osteoclastic cells.

The number of osteoclastic cells was significantly decreased after culture with CRP plus zinc at the lower concentration in the presence or absence of M-CSF and RANKL as compared with the value of each chemical alone. DNA fragmentation in adherent osteoclastic cells was stimulated after culture with CRP plus zinc in the presence of M-CSF and RANKL for 24 or $72 \mathrm{~h}$, suggesting that the combination of CRP and zinc has a potent stimulatory effect on apoptotic cells. CRP plus zinc-induced DNA fragmentation, however, was not markedly seen in adherent osteoclastic cells cultured in the absence of M-CSF and RANKL. The combination-induced DNA fragmentation may be dependent on M-CSF and RANKL.
The death of osteoclastic cells induced after culture with the combination of CRP and zinc was completely inhibited in the presence of caspase-3 inhibitor with M-CSF and RANKL. This result suggests that CRP plus zinc-induced apoptotic cell death is mediated through caspase- 3 in osteoclastic cells. It cannot exclude the possibility, however, that other molecules are related to CRP plus zinc-induced apoptotic cell death.

The expression of caspase- 3 mRNA in osteoclastic cells was significantly enhanced after culture with CRP plus zinc in the presence or absence of M-CSF and RANKL as compared with the value of each chemical alone, supporting the view that CRP plus zinc-induced apoptotic cell death is dependent on caspase-3. CRP plus zinc-induced increase in caspase-3 mRNA expression in osteoclastic cells cultured in the presence or absence of M-CSF and RANKL was completely inhibited after culture with cycloheximide, an inhibitor of protein synthesis, or DRB, an inhibitor of transcription activity. This result suggests that CRP plus zinc-enhanced caspase-3 mRNA expression in osteoclastic cells is related to newly synthesized protein synthesis.

The effect of the combination of CRP and zinc on the gene expression of molecules, related to bone resorption in osteoclastic cells, was examined in the presence or absence of M-CSF and RANKL. The expression of TRACP and cathepsin K mRNAs in osteoblastic cells was found to be significantly suppressed as compared with the value of each chemical alone. This suppressive effect was greater in the presence of M-CSF and RANKL. TRACP and cathepsin K are enzymes involved in the degradation of bone matrix components, and their enzyme activities are increased in RANKL-stimulated bone resorption $(36,37)$. It is speculated that the combination of CRP and zinc has a potentsuppressive effect on bone resorption.

$\mathrm{NF}-\kappa \mathrm{B}$ and NFATc1 are molecules related to RANKL signaling $(35,37)$. Culture with the combination of CRP and zinc caused a significant suppression of NFATc1 mRNA expression in osteoclastic cells in the presence or absence of M-CSF and RANKL. The suppression effect was greatest in the presence of M-CSF and RANKL. NF- $\mathrm{B}$ mRNA expression was not significantly changed in the presence of CRP, zinc, or CRP plus zinc. NFATc1 is a transcriptional factor which enhances the gene expression of TRACP and cathepsin $\mathrm{K}$ in osteoclasts, and the binding of NFATc1 to promoter is involved in NF- $\mathrm{KB}$ or AP-1 (37). It is speculated that the suppression of NFATc1 mRNA expression induced with the combination of CRP and zinc induces the decrease in $\mathrm{NF}-\kappa \mathrm{B}$ protein level. This may partly contribute to the decrease in the TRACP or cathepsin K mRNA expression caused by their combination. This remains to be elucidated, however.

The combination of CRP and zinc that is present in food has been shown to have a potent anabolic effect in vitro (23) and in vivo (24), suggesting that the combination of food chemical factors plays an important role in the prevention of osteoporosis with increasing age. It would be useful to identify some of the foods that are high in CRP and zinc.

In conclusion, it has been demonstrated that zinc modulates the suppressive effects of CRP on osteoclastic cells in vitro. The combination of zinc and CRP was found to have potent effects on osteoclastic cell death in vitro. 
A. TRACP

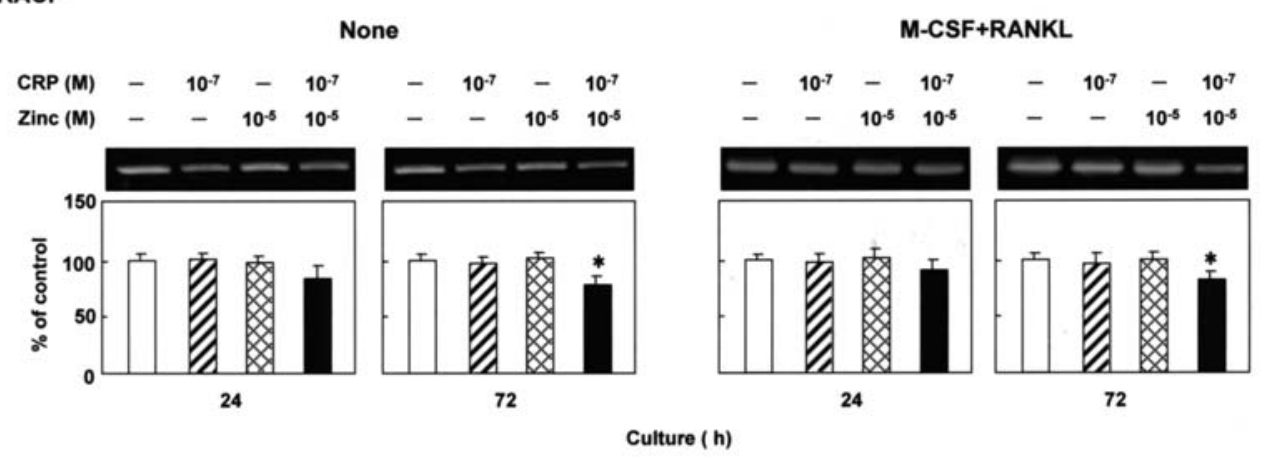

B. Cathepsin K
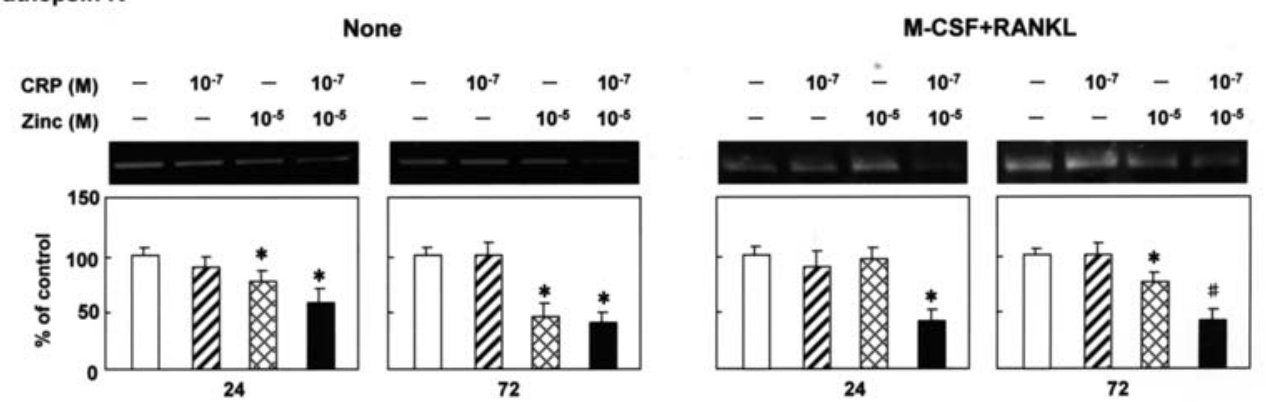

Culture ( h)

Figure 7. Effect of B-cryptoxanthin (CRP) and/or zinc on the mRNA expression of TRACP (A) or cathepsin K (B) in osteoclastic cells formed in mouse marrow culture. Osteoclasts were cultured as described in the legend for Fig. 1 . The osteoclastic cells were cultured for 24 or $72 \mathrm{~h}$ in medium containing either vehicle (1\% ethanol), CRP $\left(10^{-7} \mathrm{M}\right)$, zinc $\left(10^{-5} \mathrm{M}\right)$, or CRP $\left(10^{-7} \mathrm{M}\right)$ plus zinc $\left(10^{-5} \mathrm{M}\right)$ in the presence or absence of M-CSF $(10 \mathrm{ng} / \mathrm{ml})$ plus RANKL $(50 \mathrm{ng} / \mathrm{ml})$. Total RNAs $(2 \mu \mathrm{g})$ extracted from the adherent cells were analyzed by RT-PCR using specific primers. The figure shows one of five experiments with separate samples. The densitometric data for each mRNA level were indicated as $\%$ of control (mean \pm SEM of five experiments). ${ }^{*}<<0.01$ compared with the control (none) value. ${ }^{~} \mathrm{P}<0.01$ compared with the value for $\mathrm{CRP}$ or zinc alone.

A. NF-kB
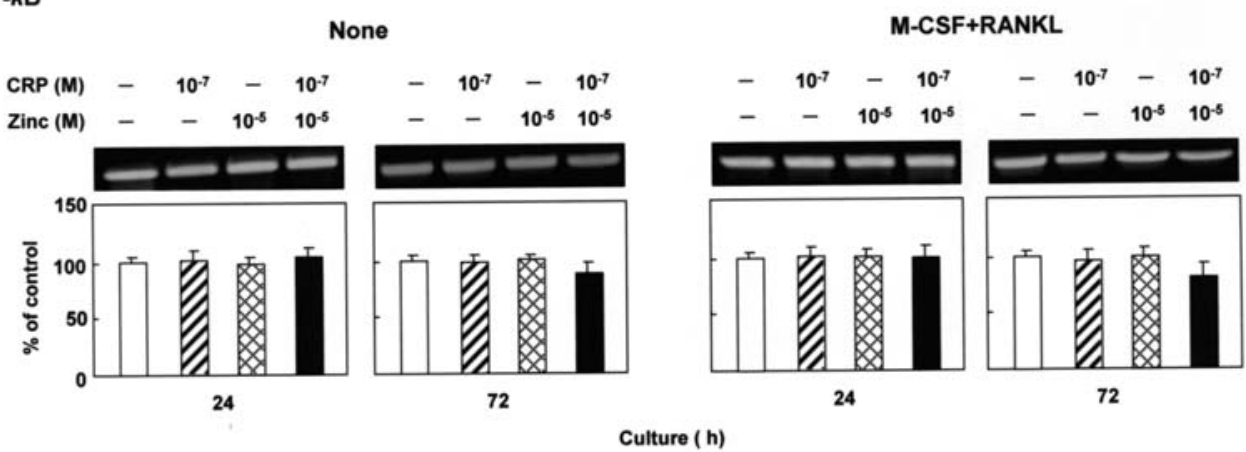

B. NFATC1
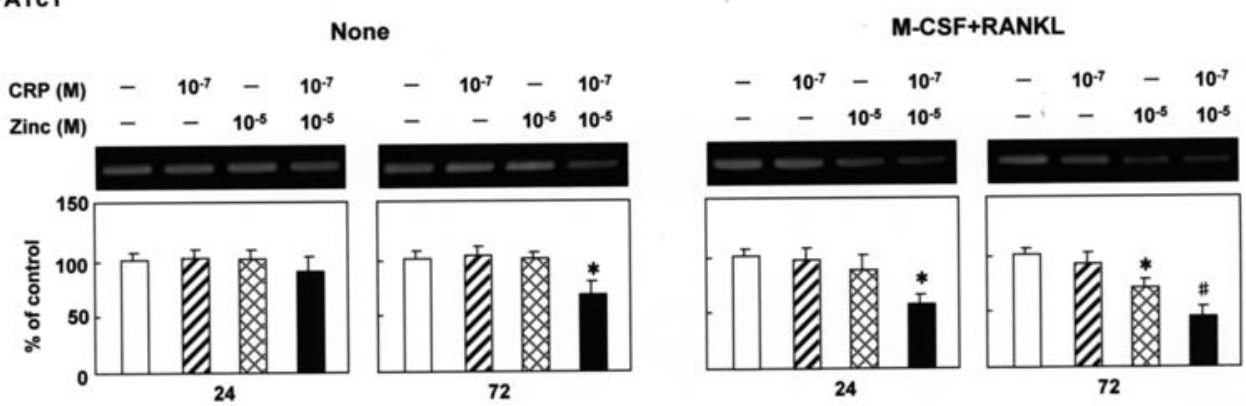

Culture ( h)

Figure 8. Effect of ß-cryptoxanthin (CRP) and/or zinc on the mRNA expression of NF- $\mathrm{B}$ (A) or NFATc1 (B) in osteoclastic cells formed in mouse marrow culture. Osteoclasts were cultured as described in the legend for Fig. 1 and treated exactly as described in the legend to Fig. 7. Total RNAs (2 $\mu$ g) extracted from the adherent cells were analyzed by RT-PCR using specific primers. The figure shows one of five experiments with separate samples. The densitometric data for each mRNA level were indicated as $\%$ of control (mean $\pm \mathrm{SEM}$ of five experiments). ${ }^{*} \mathrm{P}<0.01$ compared with the control (none) value. ${ }^{\#} \mathrm{P}<0.01$ compared with the value for CRP or zinc alone. 


\section{References}

1. Bonjour J-P, Schurch M-A and Rozzori R: Nutritional aspects of hip fractures. Bone 18: 1395-1445, 1996.

2. Yamaguchi M: Isoflavone and bone metabolism: Its cellular mechanism and preventive role in bone loss. J Health Sci 48: 209-222, 2002.

3. Yamaguchi M and Uchiyama S: Effect of carotenoid on calcium content and alkaline phosphatase activity in rat femoral tissues in vitro: The unique anabolic effect of $\beta$-cryptoxanthin. Biol Pharm Bull 26: 1188-1191, 2003.

4. Yamaguchi $M$ and Uchiyama S: ß-Cryptoxanthin stimulates bone formation and inhibits bone resorption in tissue culture in vitro. Mol Cell Biochem 258: 137-144, 2004.

5. Uchiyama S and Yamaguchi M: ß-Cryptoxanthin stimulates cell proliferation and transcriptional activity in osteoblastic MC3T3-E1 cells. Int J Mol Med 15: 675-681, 2005.

6. Uchiyama S and Yamaguchi M: B-Cryptoxanthin stimulates cell differentiation and mineralization in osteoblastic MC3T3-E1 cells. J Cell Biochem 95: 1224-1234, 2005.

7. Uchiyama S and Yamaguchi M: Inhibitory effect of B-cryptoxanthin on osteoclast-like cell formation in mouse marrow cultures. Biochem Pharmacol 67: 1297-1305, 2004.

8. Uchiyama S and Yamaguchi M: ß-Cryptoxanthin stimulates apoptotic cell death and suppresses cell function in osteoclastic cells: Change in their related gene expression. J Cell Biochem 98: 1185-1195, 2006.

9. Uchiyama S and Yamaguchi M: Oral administration of ß-cryptoxanthin prevents bone loss in ovariectomized rats. Int $\mathrm{J}$ Mol Med 17: 15-20, 2006.

10. Prasad AS, Halsted JA and Nadimi M: Syndrome of iron deficiency anemia, hepatosplenomegaly, hydroganadism, dwarfism and geophagia. Am J Med 31: 532-547, 1961.

11. Burt RE, Kahn HK and Sullivan JF: Newer aspects of the roles of zinc, manganese, and copper in human nutrition. Clin Chem 21: 501-520, 1975.

12. Hsieh HS and Navia JM: Zinc deficiency and bone formation in guinea pig alveolar implants. J Nutr 110: 1582-1588, 1980.

13. Oner G, Bhaumick B and Bala RM: Effect of zinc deficiency on serum somatomedin levels and skeletal growth in young rats. Endocrinology 114: 1860-1863, 1984.

14. Yamaguchi M, Oishi H and Suketa Y: Stimulatory effect of zinc on bone formation in tissue culture. Biochem Pharmacol 36: 4007-4012, 1987.

15. Hashizume $M$ and Yamaguchi M: Stimulatory effect of $\beta$-alanylL-histidinato zinc on cell proliferation is dependent on protein synthesis in osteoblastic MC3T3-E1 cells. Mol Cell Biochem 122: 59-64, 1991.

16. Yamaguchi M, Segawa Y, Shimokawa N, Tsuzuike N and Tagashira E: Inhibitory effect of B-alanyl-L-histidinato zinc on bone resorption in tissue culture. Pharmacology 45: 292-300, 1992.

17. Kishi S and Yamaguchi M: Inhibitory effect of zinc compounds on osteoclast-like cell formation in mouse marrow culture. Biochem Pharmacol 48: 1225-1230, 1994.

18. Holloway WR, Collier FM, Herbst RE, Modge JM and Nicholson GC: Osteoblast-mediated effects of zinc on isolated rat osteoclasts: Inhibition of bone resorption and enhancement of osteoclast number. Bone 19: 137-142, 1996.

19. Yamaguchi M: Role of zinc in bone formation and bone resorption. J Trace Elem Exp Med 11: 119-135, 1998.

20. Reginster JY, Strause LG, Saltman P and Franchimont P: Trace elements and postmemopausal osteoporosis. A preliminary study of decreased serum manganese. Med Sci Res 16: 337-338, 1998.
21. Herzberg M, Foldes J, Steinberg R and Menczel J: Zinc excretion in osteoporotic women. J Bone Miner Res 5: 251-257, 1990.

22. Kishi S, Segawa Y and Yamaguchi Y: Histomorphological confirmation of the preventive effect of $B$-ananyl-L-histidinato zinc on bone loss in ovariectomized rats. Biol Pharm Bull 17: 862-865, 1994.

23. Uchiyama S, Ihiyama K, Hashimoto K and Yamaguchi M: Synergistic effect of $\beta$-cryptoxanthin and zinc sulfate on the bone component in rat femoral tissues in vitro: The unique anabolic effect with zinc. Biol Pharm Bull 28: 2142-2145, 2005.

24. Yamaguchi M, Uchiyama S, Ishiyama K and Hashimoto K: Oral administration in combination with zinc enhances $\beta$ cryptoxanthin-induced anabolic effects on bone components in the femoral tissues of rats in vivo. Biol Pharm Bull 29: 371-374, 2006.

25. Ogasawara T, Katagiri M, Yamamoto A, Hoshi K, Takato T, Nakamura K, Tanaka S, Okayama $\mathrm{H}$ and Kawaguchi $\mathrm{H}$ : Osteoclast differentiation by RANKL requires $\mathrm{NF}-\kappa \mathrm{B}-$ mediated down regulation of cyclin-dependent kinase $6(\operatorname{cdk} 6)$. J Bone Miner Res 19: 1128-1136, 2004.

26. Burstone MS: Histochemical demonstrations of acid phosphatase with naphthol AS-phosphate. J Natl Cancer Inst 221: 523-539, 1958 .

27. Minkin C: Bone acid phosphatase: Tartrate-resistant acid phosphatase as a marker of osteoclast function. Calcif Tissue Int 34: 285-290, 1982.

28. Preaux A-M, D'Oratho M-P, Bralet M-P, Laperche Y and Mavier P: Apoptosis of human hepatic myofibroblasts promotes activation of matrix metalloproteinase-2. Hepatology 36: 615-622, 2002.

29. Ceriotti G: Determination of nucleic acids in animal tissues. J Biol Chem 214: 59-70, 1955

30. Chomczynski P and Sacchi N: Single-step method of RNA isolation by acid guanidium thiocyanate-phenol-chloroform extraction. Anal Biochem 162: 156-159, 1987.

31. Juan TS, McNiece IK, Jenkins NA, Gilbert DJ, Copeland NG and Fletcher FA: Molecular characterization of mouse and rat CPP32 beta gene encoding a cysteine protease resembling interleukin-1 beta converting enzyme and CED-3. Oncogene 13: 749-755, 1996.

32. Cassady AI, King AG, Cross NC and Hume DA: Isolation and characterization of the genes encoding mouse and human type-5 acid phosphatase. Gene 130: 201-207, 1993.

33. Rantakokko J, Aro HT, Savontaus M and Vuorio E: Mouse cathepsin K: cDNA cloning and predominant expression of the gene in osteoclasts, and in some hypertrophying chondrocytes during mouse development. FEBS Lett 393: 307-313, 1996.

34. Li X, Ho SN, Luna J, Giacalone J, Thomas DJ, Timmerman LA, Crabtree GR and Francke U: Cloning and chromosomal localization of the human and murine genes for the $\mathrm{T}$-cell transcription factors NFATc and NFATp. Cytogenet Cell Genet 68: 185-191, 1995.

35. Ghosh S, Gifford AM, Riviere LR, Tempst P, Nolan GP and Baltimore D: Cloning of the p50 DNA binding subunit of NFkappa B: Homology to red and dorsal. Cell 62: 1019-1029, 1990.

36. Zaidi M, Blair HC, Moonga BS, Abe E and Huang CL: Osteoclastogenesis, bone resorption, and osteoclast-based therapeutics. J Bone Mine Res 18: 599-609, 2003.

37. Asagiri $M$ and Takayanagi $H$ : The molecular understanding of osteoclast differentiation. Bone 40: 251-264, 2007. 